\title{
REDRESSING DIGITAL ORIENTALISM: VIETNAMESE CULTURAL PROFESSIONALS' DIGITAL WORK DURING THE COVID-19 PANDEMIC
}

\section{Remediar o orientalismo digital: trabalho digital dos profissionais culturais vietnamitas durante a pandemia covid-19}

\section{Corregir el orientalismo digital: el trabajo digital de los profesionales de la cultura vietnamita durante la pandemia de Covid-19}

Emma L. Duester

Lecturer, RMIT University (Royal Melbourne Institute of Technology) e-mail:emma.duester@rmit.edu.vn

Michal A. Teague Associate Lecturer, RMIT University (Royal Melbourne Institute of Technology) e-mail:michal.teague@rmit.edu.vn

\section{Resumo}

O estudo atual investiga como as tecnologias digitais podem potencialmente ser usadas para reorientar a narrativa global sobre o Vietname, superar um desequilíbrio na representação e ajudar a corrigir o orientalismo digital. As tecnologias digitais globais permitem que profissionais culturais vietnamitas ultrapassem as fronteiras da sua nação e se tornem parte do mundo da arte global. Com isto, podem participar na produção, divulgação e circulação de discursos sobre arte e cultura a nível global. Ao fazê-lo, podem corrigir o orientalismo digital contemporizando narrativas sobre o Vietname. No entanto, existe uma tensão subjacente, pois o próprio meio pelo qual as suas vozes são ouvidas é conseguido através da utilização de tecnologias, ferramentas e plataformas globais (ocidentais). A investigação usa uma etnografia digital das páginas de Facebook de 7 espaços de arte contemporânea em Hanói e 20 entrevistas semi-estruturadas com profissionais da arte e cultura em Hanói. As entrevistas foram realizadas durante a Pandemia Covid-19 e abordaram o seu impacto e utilização da tecnologia digital no seu trabalho durante este tempo.

Palavras-chave: Orientalismo digital. Profissionais do sector cultural do Vietname. Pandemia da COVID-19 


\begin{abstract}
The current study investigates how digital technologies can potentially be used to re-orientate the global narrative on Vietnam, overcome an imbalance in representation and help redress digital orientalism. Global digital technologies allow Vietnamese cultural professionals to reach beyond the borders of their nation and to become part of the global art world. With this, they can participate in the production, dissemination, and circulation of discourses on art and culture globally. In doing so, they can redress digital orientalism by contemporizing narratives on Vietnam. However, there is an underlying tension, as the very means by which their voices are heard is achieved by using global (western) technologies, tools and platforms. The research uses a digital ethnography of the Facebook pages of 7 contemporary art spaces in Hanoi and 20 semi-structured interviews with art and cultural professionals in Hanoi. The interviews were carried out during the Covid-19 Pandemic and addressed its impact and use of digital technology in their work during this time.
\end{abstract}

Key words: Digital orientalism. Vietnam cultural sector professionals. Covid-19 pandemic.

\title{
Resumen
}

El estudio actual investiga cómo las tecnologías digitales pueden ser potencialmente utilizadas para reorientar la narrativa global sobre Vietnam, superar un desequilibrio en la representación y ayudar a corregir el orientalismo digital. Las tecnologías digitales globales permiten a los profesionales de la cultura vietnamitas llegar más allá de las fronteras de su nación y convertirse en parte del mundo del arte global. Con esto, pueden participar en la producción, difusión y circulación de discursos sobre arte y cultura a nivel global. Al hacerlo, pueden corregir el orientalismo digital contemporizando narrativas sobre Vietnam. Sin embargo, existe una tensión subyacente, ya que el mismo medio por el cual se escuchan sus voces se logra mediante el uso de tecnologías, herramientas y plataformas globales (occidentales). La investigación utiliza una etnografía digital de las páginas de Facebook de 7 espacios de arte contemporáneo en Hanoi y 20 entrevistas semiestructuradas con profesionales del arte y la cultura en Hanoi. Las entrevistas se realizaron durante la Pandemia de Covid-19 y abordaron su impacto y uso de la tecnología digital en su trabajo durante este tiempo.

Palabras clave: Orientalismo digital. Profesionales del sector cultural de Vietnam. Pandemia de COVID-19. 


\section{INTRODUCTION}

The advent of the 'fourth industrial revolution' has brought advances in digitalization in Vietnam. However, it remains disadvantaged on a global level due to country-specific challenges. The challenges in lack of budget, technical resources and human resources experienced in developing countries such as Vietnam can impede or slow down the digitization process and, hence, further increase the digital divide. The global digital divide deeply impacts access, inclusion and representation and the ability to preserve, archive, curate, exhibit and steward traditional and contemporary art and culture in Vietnam. This means it is important to identify what work is being done to digitize art and culture in Vietnam and to understand how it can provide a way to overcome the digital divide and the effects of digital orientalism. This paper argues that geopolitical and socio-economic factors are limiting Vietnamese cultural professionals' ability to adopt new technologies, thus exacerbating the digital divide.

The nature of work in the art and cultural sector in Hanoi, Vietnam, is changing. The new generation of cultural professionals are harnessing digital technology to display art and cultural collections in innovative and creative ways. Digitization today is not only about creating 'hidden' digital archives but, instead, curating digital art and culture experiences that are publicly accessible. This allows a way to both preserve and digitally display culture in a contemporary format. Whilst some developments in digitization were taking place prior to the Covid-19 pandemic, importantly, the Covid-19 pandemic has accelerated the pace of technology adoption and increased the rate of developments in digitization.

The paper presents findings from 20 semi-structured interviews with cultural professionals in Hanoi during the Covid-19 pandemic, on how they adapted during lockdown and how their use of digital technologies and digital platforms changed. The paper also presents the findings from a digital ethnography of cultural professionals' use of Facebook during the Covid-19 pandemic, including the lockdown period in Hanoi (March-April 2020). It provides a broader perspective on the web by combining analysis of web data (Facebook posts) and offline data from interviews with artists, art spaces and museums, in order to better understand individuals and organisations online and offline behaviour and their use of digital platforms and technology during this time. 
It is important to chart the changes happening in this sector during the Covid-19 pandemic, as it has accelerated the digitization of culture. There has been a shift towards creativity as a form of community resilience with the migration from physical spaces to virtual spaces [British Council, 2020]. The increased use of and reliance upon digital platforms has made cultural professionals work in more diverse ways, producing new types of content specifically for online platforms and finding new ways of communicating with audiences. The main research question therefore is: What has been the impact of the Covid-19 pandemic on developments in digitization and the uptake of digital technologies for work in the art and cultural sector in Hanoi?

\section{DEVELOPMENT}

The methodological approach combined online and offline modes of data collection: (1) a digital ethnography of 7 art spaces' Facebook pages and (2) 20 semi-structured interviews. A digital ethnography was conducted on the Facebook pages of 7 independent contemporary art spaces over 4 months, between January and April 2020. This time period was chosen purposefully because it included the period before, during and after lockdown in Hanoi. This allowed an observation of the changes in digital communication, types of content, and the overall changes in the function of Facebook for the art spaces. This methodology provided a broader perspective on the web by combining an analysis of online data (Facebook posts) and offline data from interviews to better understand individual and organizational behaviour and use of digital technology and platforms during this time.

7 independent, contemporary art spaces were selected; hence, this is a case study and is not generalisable. Purposive sampling was used to select a particular segment of the art and culture sector in Hanoi. This segment works independently of government funding and are not part of national digitization projects (rather than state museums or commercial galleries). Also, all 7 art spaces use English language as well as Vietnamese language on their Facebook pages to appeal to local and international audiences. Facebook was chosen as the sole platform for analysis because it is the most used media platform for art spaces in Hanoi, and Vietnam more widely for professional work. All the art spaces in the sample stated that Facebook is the main mode of communication utilized on a daily basis.

The selection comprised 75 Facebook posts, representing only a portion of all posts during this time period. It was not possible to capture all the posts during this time due the nature of the Internet and algorithms. As Banaji and Buckingham (2013, p. 15) argue, "the 
Internet is a decentralized medium, and it is impossible to gain a comprehensive picture of everything that is available online, much less construct a representative sample of it." Accordingly, a discrete selection of posts was analysed and combined with interview analysis to triangulate results to mitigate this limitation. The examples included in the results section of the paper demonstrate the overall findings of the analysis.

The methodology included 20 semi-structured interviews with cultural professionals across Hanoi. Participants were initially recruited based on RMIT (Royal Melbourne Institute of Technology) University's links with industry partners in the art and cultural sector. Snowball sampling was used to recruit further participants. The selection criteria were: (1.) they work in the art and cultural sector in Hanoi and (2.) participants are Vietnamese. The interviews were carried out from May to November 2020. 7 of the interviewees were the cofounders or curators of art spaces included in the digital ethnography sample. The other 13 interviewees included curators, museum directors, museum communication directors, art and culture media, university and art school directors, auction house directors, artists and commercial gallery directors.

\subsection{Social Media Sites and Digital Orientalism}

Many scholars discuss ways that social media sites provide audiences with agency (RUSSO and WATKINS, 2005, pp. 4-17.; FORTE, 2005). For instance, Russo and Watkins (2005, pp. 4-17.) argue "convergent technology has promised the delivery of multi-channel, multi-platform content where choice is in the hands of the consumer" and that audiences are empowered through enabling access to content on their own terms. However, social media sites also provide cultural professionals with agency. Social media sites give these professionals agency to create content and participate in the global discourse on art and culture; this is especially important for developing countries such as Vietnam, as this can provide a way to redress the imbalance in representation on Vietnamese art and culture globally.

However, digital platforms like Facebook are created and controlled by the West and shaped on Western ideology, which determines how it can be used by cultural professionals in Vietnam. As Morley and Robins (1995, pp. 167.) argue, technology "reaffirms the essential (that is civilizational) supremacy of Western culture." This can be seen in the imbalance in the amount of content available online, algorithms that are controlled by large corporations that perpetuate existing biases, platform 'terms and conditions' that reflect the morals and rights of 
western societies, and technical requirements in translation from Vietnamese to English. For instance, the current limitations of word count on Facebook can present a challenge for professionals wishing to publish dual language posts for their Vietnamese and Englishspeaking audiences.

The idea and perception of digital platforms has changed during the Covid-19 pandemic, as the affordances of digital technologies come into clearer view as people increasingly use and need them. Research on how digital culture and digitality provide a sense of community (GERE, 2012, pp. 1-17; SADIKU et al, 2017, pp. 33-34.) is relevant as audiences isolated during social distancing have required a feeling of community, togetherness and touch. For instance, Gere (2012, pp. 1-17.) discusses how digitality has replaced the sense of community that has been lost in society. The affordance of Facebook is that it provides a (substitute) sense of community. This is due to how "digital networks encourage greater connectivity, collaboration, communication, community and participation" (GERE, 2012, p. 1). Gere (2012, p. 2) also discusses how the digital provides a pseudofeeling or pseudo-sense of touch, arguing that new technologies "exemplify the gap inherent in touch" and "invoke tropes of touch," whereby people can view and experience an interplay of senses. This has become especially important during the Covid-19 pandemic, as Facebook has been one space where sensory, immersive and experiential experiences are still possible.

\subsection{Digitisation in the Art \& Culture Sector in Vietnam}

Across Asia, discussion is taking place on policy around preserving cultural heritage (NGUYEN, 2019, pp.3; VIETNAM GOVERNMENT GOVERNMENT, 2019, web.; and BRITISH COUNCIL, 2018, web.). However, in Vietnam there is minimal discussion on digitization strategy and processes nor policy discussion regarding agreement on professional standards and practices. This is the case even as a lot of art and culture is transitioned to online platforms, transferred to digital formats and the amount of exhibitions online is increased. As Miles and Green (2008, pp. 1-81) argue there are few studies of innovation in the creative industries, especially with regards to technological innovation and the digitization of content driving major changes in the creative industries.

Digitization projects have been taking place in the art and cultural sector in Hanoi, including scanning images, objects and photographs for preservation or to create digital archives. However, these digital archives and collections have not been used for public engagement but, rather, solely for preservation and archiving. For this reason, art and cultural 
organisations are only just initiating work on the public display of and access to digitized collections. The collections of many state-run art and cultural institutions in Hanoi are not publicly displayed on a digital platform because the means for digitization onto apps or digital platforms has yet to be utilized or resourced effectively. Whereas independent organisations have had to innovate to survive and so are harnessing digital technologies more readily.

This demonstrates that there has been an evolution in the use of digital technologies for work in the creative industries, especially with regards to non-profit art organisations in Hanoi. This has been accelerated by the pandemic, as cultural professionals were required to utilize digital platforms for work and audience communication. This is important for redressing digital orientalism, the use of free, open-access digital platforms can help redress the current imbalance in cultural content online, enabling Vietnamese cultural professionals to determine the narrative on and contribute to the global discourse on art and culture.

\subsection{Changes to \& Resilience in Cultural Professionals Digital Work During Covid-19}

The Covid-19 pandemic, and especially, the lockdown in Hanoi (March-April 2020), made many cultural professionals focus on their digitization projects and digital work practices. This allowed many spaces time to develop a digital strategy for their use of social media platforms. For example, participant 3 from Nho Que says they created a strategy at the start of the lockdown, in terms of which platforms were best for connection: "we decided on two platforms to communicate with the audience - Facebook and YouTube." Many said that this time allowed them to develop their use of Facebook in particular, to develop a digital communication strategy. For instance, participant 5 from Ba Thin says their strategy during the lockdown was "to exploit the advantage of online media platforms like Facebook."

There was an increase in the amount of artworks digitized and other visual content published on Facebook. Participant 2 from Phò Dày says this time accelerated digitization projects: "the archive idea started before the pandemic, but this time gave me time to think and work on it." Participant 6 from Luc Nam similarly described how lockdown afforded them time to do the online projects they had wanted to do, saying "we decided to focus on all those projects that always seem to get set aside when we are receiving the public regularly." Participant 7 from Bac Giang also digitized more artworks and other content (text, video, event posters), saying "we develop and focus more on digital content, more updated information and images of artworks." Participant 9 from Bac Khe also discussed the increased 
amount of and importance of digitization at this time: "after lockdown, the digitized works became more important and can support more for the physical." At this moment, digital platforms became essential for the continuation of their work practices and maintaining connection with audiences.

This time also led to a migration of work practice to online platforms. Some participants said they used a wider range of digital platforms. In addition, they used a wider variety of digital platforms for different purposes: participant 5 from Ba Thin says, "we used more digital platforms." As well as using Facebook for archiving, communication and exhibition, it is now also being used increasingly for work practices. As participant 5 says, Ba Thin used a wider variety of social media platforms and each had a particular function for their work practices: "Facebook and Zalo to work together, Zoom and Teams to organize seminars and talks, website to organize online courses in art." As participant 7 from Bac Giang says, "during lockdown we applied some changes [...] we switched to online working." Participant 1 from Gâm mentions that they organized many projects online between colleagues and collaborated internationally online with other professionals.

Facebook was used as a tool for connection. Participant 13 from Beilun refers to how "the digital has the potential of globalization and for connecting people." Similarly, participant 3 from Nho Que says, they "connected with visitors and the public via social networks such as Facebook, Twitter, Instagram, YouTube and the website." Participant 3 realised the potential of digital platforms at this time for connection, saying "the essence of digital technology is the creativity, without borders, and it is constantly developing and bringing people together." Participant 3 also states that digital platforms act like a "bridge," connecting Nho Que and the audience, as "we use social networks as a bridge to connect Nho Que with domestic and foreign visitors." Participant 14, Director of Nho Que, says "we use online to bring the museum closer to the audience."

Other participants mention the importance of maintaining connection during lockdown for keeping people's spirits high and providing the role of a community centre, through information updates, inspiration and emotional consolement. Participant 12 from Thao says they "continued to maintain connection with the audience, promote a dynamic and creative spirit throughout organizing art events, like workshops and talks in the form of online, to help spread positive energy in the time of instability." A positive communication style and strategy was applied by participant 12: "I will apply a positive way of thinking, look at the bright spots in real conditions and find a way to make the best of what is available to turn the situation 
around." Thao used artworks with new associations and meanings to convey messages of hope, support and togetherness throughout the lockdown period.

\subsection{Cultural Professional's Use of Facebook During the Covid-19 Pandemic}

The Facebook posts published by the 7 art spaces during the Hanoi lockdown share some key stylistic features. This is evidence of changes in their use of Facebook during this time. The digital ethnography undertaken identified 4 basic types of posts:

1. Emotional consolement: posts that console the audience, using artwork to convey messages of hope, togetherness, touch and connection.

2. Inspirational Quotes: posts that uplift and motivate the audience with the use of messages of the positive feelings of strength and togetherness.

3. International links: posts with images of international events, which the art space is either organizing, is a part of, or is about what another art space is organizing.

4. Digital Display and Exhibition: Using the platform in new ways such as previews of inside the art space and creating Covid-19 related online content, artworks and exhibitions.

Art Space 1 posts were emotionally consoling messages about hope and companionship during the time of lockdown. Flowers and nature became key images posted at this time. In the post Art Space 1 says the flowers are important as substitutes for social contact and companionship. A post from Art Space 3 also demonstrates a consolement type post in a photographic image of hands touching photographs on a table. The perspective allows the viewer to feel as if those arms and hands could belong to them, to simulate the nature of touch. Facebook provides a means to 'be in touch' and connect with others; however, this shows how Facebook can also be a means 'to touch.'

Art Space 2 also provides emotional consolement with a series of lacquer paintings iv and accompanying text that reads: "We do believe in the power of art, especially during this period-of-time, because art brings hope, brings communities together. Paintings, installations, literature, film, music are always considered to be the repository of a society's collective memory" (ART SPACE 2, Facebook Post, $23^{\text {rd }}$ April 2020). Other posts provide inspirational messages of well-being, such as "art can feed the soul" and "everything will be alright" (ART SPACE 2, Facebook Post, $16^{\text {th }}$ April 2020) 
The communication in posts is also directed to international collaborations with other art spaces or cultural professionals in other countries. For instance, Art Space 6 refers to collaborations with Singapore and Italy. Another example is a post by Art Space 7 encouraging Vietnamese artists to participate internationally and continue working through this time of lockdown. Art Space 7 announced an open call for an artist project between Vietnam and Germany. Another similar online announcement and promotion of international events was an exhibition collaboration between Romanian, French and Vietnamese artists. The space also directed its audience to online events and museums providing virtual exhibition tours, stating "Covid-19 doesn't affect good online events like this event of teammates" (ART SPACE 7, Facebook Post, 19th April 2020). Art Space 5 also became a resource for artists and cultural professionals, sharing information and stories about international film festivals, such as IDFA (based in Amsterdam). "There are various activities professionals can take part in such as screenings, projects, support funds, training programs, networking... See more at: https://www.idfa.nl/en/" [(ART SPACE 5, Facebook Post, 23rd April 2020).

Art spaces also used the platform for digital display and exhibition type posts at times creating artwork in response to the lockdown. Art Space 3 posted a photograph from inside the living room of a professional photographer working in Hanoi. Photographers were asked to document their daily life during lockdown through photographs, to respond to this moment of 'working from home' which were then posted on their Facebook page. These photographs provided "snapshots of daily reality," as the accompanying text states (ART SPACE 3, Facebook post, $11^{\text {th }}$ April 2020). "With social distancing come cancelled shoots, change of plans, and an unfulfilled need to be out in the world. We have reached out to seven photographers working in different fields to ask how the outbreak has impacted their work" (ART SPACE 3, Facebook post, $11^{\text {th }}$ April 2020).

During this time Art Space 2 uploaded a series of artworks on several separate occasions over this 4-month period. This time was distinct from previous uploads of artworks onto Facebook as it was curated like an exhibition space. A long-written piece about the artwork and background artist information accompanied each image. This meant they had the opportunity to digitize more of the artworks in their collection and more strategically curate content. Another instance of digitization and display is the artwork series entitled 'A Good Day' commissioned to respond to this moment and specifically for their Facebook page. 
Art Space 3 used photographs to tell their audience their own story during this time, in terms of their development and daily updates. Art Space 3 uploaded and posted photographs of some of the artworks in an exhibition this acted like a preview to the actual exhibition for their audience. These photographs on Facebook simulated the feeling of a virtual exhibition tour with whole-room views, which helped the audience feel as if they were in the exhibition in the physical sense.

\section{Final Considerations}

The current study highlights the challenges and opportunities associated with digitization in Vietnam. On one hand, digitization provides a means of sustainable preservation and can provide a way to overcome issues in archiving and preserving cultural heritage. It can also allow cultural professionals an agency to present Vietnamese art and culture to local and international audiences. This has the potential to redress the imbalance in representation and to counter digital orientalism, which exists in the differing amounts of content available and the quality of content online due to uneven access to high-quality technologies and algorithms that perpetuate bias towards content from the West. However, on the other hand, there are challenges such as the need for skilled professionals dedicated to this role and equipment that can be used to properly digitize artworks.

The findings show how participants adapted and became resilient in overcoming challenges by using the free, open platform of Facebook more frequently and in more experimental ways. This can provide a solution to having their voice heard globally, yet it must be acknowledged that this is a global western technology and company for profit. However, there is a concern regarding the increasing gap between developed countries and developing countries produced by digital technologies. While the former is creating and producing the technologies, the latter must use these digital technologies even though they do not 'fit' with their own cultural codes, morals and ethics. They must use western technology platforms as there is no alternative - western platforms dictate how they can work and use these platforms.

The work of Vietnamese art and cultural professionals is shaped by an implicit understanding of the digital divide, social inequalities and digital orientalism. Many of the interviewees felt they must disseminate their work and art to a global audience to overcome power relations and hierarchies that designate some places as 'centres' and others as 'peripheries.' The analysis found less social capital between art and cultural organisations in 
Hanoi and more focus on international connections. This is partly as they consider international connections can be more 'valuable' than local connections, which again relates to the local-global power hierarchies and relations that exist. They must employ global technologies as there is no other alternative; for instance, Zalo is a popular Vietnamese social media platform, but it would not have the equivalent reach.

Social media platforms provide agency and empowerment and can be legitimized as an effective tool for work in the art and cultural sector in Vietnam. This is the case because there has been a strategic use of this social media site, which has led to a change in the function of the social media site for work for art and cultural professionals. Digitization practices on Facebook demonstrate that for them it is not only about archiving and preserving culture, but also about selection, curation and representation.

\section{Acknowledgements}

This research is funded by RMIT University, with an Internal Research Grant. The grant was issued in January 2020 but was redacted due to the Covid-19 pandemic. It was re-instated in January 2021 and will continue until December 2021. The grant number is: IRG-2021 - GRANT R3.

\section{REFERENCES}

Banaji, S. and Buckingham, D. (2013). The Civic Web: Young People, the Internet, and Civic Participation. Massachusetts: The MIT Press. https://doi.org/10.7551/mitpress/8949.001.0001

Benghazi, P-J., Salvador, E., Simon, J-P. (2018). 'The race for innovation in the media and content industries: legacy players and newcomers. Lessons from the music and newspaper industries,' in Digital Platforms and Cultural Industries, edited by Bouquillion Philippe and Moreau Francois, ICCA-Cultural industries, artistic creation, digital technology, vol. 6, pp. 21-40, Peter Lang editions. https://doi.org/10.3726/b14814

British Council. (2020). Creative innovation in the East Asia arts and culture sector. Available online at: https://www.britishcouncil.org/research-policy-insight/insightarticles/creative-innovation-east-asia-arts-culture. Last accessed: 26 January 2021.

Clayton, D. (2009). The dictionary of human geography. 5th edition ed. Oxford: WileyBlackwell, pp. 94-98. https://doi.org/10.1016/b978-008044910-4.00978-0

Forte, M. (2005). 'Ecology of the Virtual: New Scenarios of Virtual Heritage,' Papers presented to the $11^{\text {th }}$ International Conference on Virtual Systems and Multimedia in Ghent, Belgium, 27 October 2005. Available online at: 
https://belgium.vsmm.org/pages/program_tuesday_keynotes.html\#2Loan 2014. Last accessed 25th January 2021.

Gere, C. (2012). 'Digitality' in Community without Community in Digital Culture. London: Palgrave Macmillan, pp. 1-17. https://doi.org/10.1057/9781137026675_1

Miles, I. and Green, L. (2008). Hidden Innovation in the Creative Industries, NESTA Report, July, pp. 1-81.

Morley, D. and Robins, K. (1995). Spaces of Identity: Global Media, Electronic Landscapes and Cultural Boundaries. London and New York: Routledge, pp. 167.

Nguyen, C. B. (2013) 'Preface' in VICAS (2013) The Development of the Cultural Industries in Vietnam: to 2020, Vision 2030 (Draft version). Hanoi: Vietnam Institute of Culture and Art Studies (VICAS). pp.3. https://www.britishcouncil.vn/sites/default/files/national-strategy-forthe-development-of-cultural-industries-to-2020-vision-2030.pdf Accessed 20 April 2020.

Otzmagin, N. and Ben-Ari, E. (2020). Creative Context: Creativity and Innovation in the Media and Cultural Industries. Singapore: Springer Singapore.

https://doi.org/10.1007/978-981-15-3056-2

Porter, M. E. and Heppelman, J. E. (2014). 'How Smart, Connected Products Are Transforming Competition.’ Harvard Business Review, November 2014 Issue. https://hbr.org/2014/11/howsmart-connected-products-are-transforming-competition. Accessed 20 March 2020.

Russo, A. and Watkins, J. (2005). 'Digital Cultural Communication: enabling new media and co-creation in Asia' in International Journal of Education and Development using ICT, 1(4), pp.4-17. https://doi.org/10.1145/1056224.1056245

Sadiku, M. N. O., Tembely, M., Musa, S. M. and Momoh, O. D. (2017). 'Digital Culture' in International Journals of Advanced research in Computer Science and Software Engineering Vol. 7, Iss. 6, pp. 33-34. https://doi.org/10.23956/ijarcsse/v7i6/01613

Tipton, F. B. (2002). 'Bridging the Digital Divide in Southeast Asia: Pilot Agencies and Policy Implementation in Thailand, Malaysia, Vietnam, and the Philippines' in ASEAN Economic Bulletin, 19(1), pp. 83-99. https://doi.org/10.1355/ae19-1f

UNESCO (2017). 'Forward' in Re/Shaping Cultural Policies: Advancing Creativity for Development. 2005 Global Convention Report. Paris: United Nations Educational, Scientific and Cultural Organization, pp. 3-4.

Socialist Republic of Vietnam Governmental Portal. (2019). Viet Nam Sustainable Development Strategy for 2011-2020.

http://www.chinhphu.vn/portal/page/portal/English/strategies/strategiesdetails?categoryId=30 \&articleId=10050825. Accessed 18 December 2019. 


\section{Emma Duester}

EMMA DUESTER, PhD is a Lecturer in the School of Communication and Design at the RMIT University (Royal Melbourne Institute of Technology). She is leading a research team exploring the digitization of the art and culture sector in Hanoi, Vietnam. She is the author of

'The Politics of Migration and Mobility in the Art World: Transnational Baltic Artistic

Practices Across Europe,' published by Intellect in 2021. Her areas of research interest include the creative industries, art and culture sector, digital technologies, and transnational communication.

\section{emma.duester@rmit.edu.vn}

Michal Teague

MICHAL TEAGUE, MAPS is an Associate Lecturer in Design Studies at RMIT University Vietnam (Royal Melbourne Institute of Technology). For the past 10 years, Michal has worked professionally as a transnational practitioner and educator in art, design and communication in the Middle East and Vietnam. Michal's areas of research and creative praxis are social and strategic design, creative and cultural industries, urban spaces and ecology, transnational design pedagogy and praxis-led research.

michal.teague@rmit.edu.vn

\section{(C) $\odot \Theta(-$}

This work is licensed with a License

Creative Commons Attribution-NonCommercial-ShareAlike 4.0 International 